\title{
Reproductive ecology of two pioneer legumes in a coastal plain degraded by sand mining ${ }^{1}$
}

\author{
Adriana de Oliveira Fidalgo ${ }^{2,3}$, Débora Marcouizos Guimarães², Gabriela Toledo Caldiron² and \\ José Marcos Barbosa²
}

Received: 22.08.2017; accepted: 19.12.2017

\begin{abstract}
Reproductive ecology of two pioneer legumes in a coastal plain degraded by sand mining). The present study evaluates and compares the phenology, pollination biology and breeding systems of Chamaecrista desvauxii (Collad.) Killip. and Clitoria laurifolia Poir. in a coastal plain degraded by sand mining in São Paulo State, Brazil, from January 2006 to May 2008. Flowering and fruiting events occurred in the warm and rainy season. Both species are self-compatible but only C. desvauxii was pollinator-dependent to set fruits. A small group of bees, comprising Eufrisea sp., Eulaema (Apeulaema) cingulata and Bombus morio, accessed the male and female floral structures and moved among individuals resulting in crosspollinations. However, only B. morio was a frequent visitor and an effective pollinator. Although recruitment and survival of population in the study area are high for both species, we observed lower abundance and richness of visitors suggesting the possible lack of pollinators and pollen limitation.

Keywords: Bee pollination, Bombus, Fabaceae, disturbed areas, pollen limitation
\end{abstract}

RESUMO - (Ecologia reprodutiva de duas leguminosas pioneiras em planície costeira degradada por mineração). O presente estudo avaliou e comparou a fenologia, a biologia da polinização e os sistemas de reprodução de Chamaecrista desvauxii (Collad.) Killip.and Clitoria laurifolia Poir. em uma planície costeira degradada pela mineração de areia em São Paulo, Brasil, entre janeiro de 2006 a maio de 2008. A floração e a frutificação ocorreram na estação quente e chuvosa. Ambas as espécies são autocompativeis, mas apenas $C$. desvauxii foi dependente do polinizador para produzir frutos. Um pequeno grupo de abelhas, incluindo Eufrisea sp., Eulaema (Apeulaema) cingulata e Bombus morio, tocou as estruturas florais masculinas e femininas e se movimentou entre indivíduos levando a polinizações cruzadas. No entanto, apenas B. morio foi um visitante frequente e um polinizador eficaz. Embora o recrutamento e a sobrevivência da população na área de estudo sejam elevados para ambas as espécies, observou-se reduzida abundância e riqueza de visitantes, indicando uma possível falta de polinizadores e limitação polínica.

Palavras-chave: áreas degradadas, Bombus, Fabaceae, limitação polínica, polinização por abelhas

\section{Introduction}

Habitat loss, fragmentation and the consequent loss of biodiversity are the main environmental impacts of human activities (Primm \& Raven 2000). Such impacts may increase pollination failure as both pollen quantity and quality often decrease as populations become isolated (Lazaro \& Traveset 2006, Alonso et al. 2013, Suarez-Gonzales \& Good 2014). The susceptibility of a plant species to habitat fragmentation is related to its reproductive biology, which reflects its degree of dependence on pollinators (Liu \& Koptur 2003, Aguilar et al. 2006, Warzecha et al. 2016). Studies on breeding systems of plants in disturbed areas can provide relevant information about facilitation, competition for pollinators and reproductive success (Kearns et al. 1998, Martínez 2003, Ghazoul 2006, Brito et al. 2010). Furthermore, to assess the reproductive attributes of colonizing plants is important role for restoration programs in order to establish succession processes allowing the formation of a self-sustaining vegetation (Rosales et al. 1997).

The Brazilian Atlantic Forest is a tropical rainforest on mountain slopes bordered by coastal

1. Parte da Dissertação de Mestrado do segundo Autor

2. Instituto de Botânica, Núcleo de Pesquisa em Sementes, Avenida Miguel Estéfano 3.687, 04301-012, São Paulo, SP, Brasil

3. Corresponding author: aofidalgo@hotmail.com 
plains, which have semi deciduous forests and open scrub vegetation on marine sand deposits (Scarano 2002). Coastal plains are heavily impacted worldwide by accelerated urban growth and increasing human population density, as a consequence, the so-called 'Restingas' (sandy coastal plains vegetation) have been considerably degraded (Zamith \& Scarano 2006, Martínez et al. 2006, Rocha et al. 2007). Damage to coastal environments by anthropogenic activity are mainly deforestation, soil degradation by landfills and mining, siltation and pollution of watercourses and constructions on the beaches and areas of environmental protection (Rocha et al. 2007, Amorim \& Oliveira 2009). On coastal plains degraded by sand mining, deforestation is followed by topsoil removal and other soil disturbances.

Chamaecrista desvauxii (Collad.) Killip and Clitoria laurifolia Poir (Fabaceae) are shrubby herbaceous, pioneer species found in degraded areas preferentially in sandy soils (Kissman \& Groth 1995, Sacramento et al. 2007). Different species of both genera are commonly found on coastal plains of several countries and their population dynamics could be associated with habitat degradation and destruction (Martínez et al. 2006, Sacramento et al. 2007, ArceoGómez et al. 2012, Silva et al. 2014). Such different species are described as partially self-compatible, although they could be pollinator-dependent for fruit set (Manente-Balestieri \& Machado 1999, Tandon et al. 2003, Nair et al. 2004, Kleunen \& Johnson 2005, Galloni et al. 2007, Arone et al. 2012).

The present study assesses and compares the pollination biology and the breeding systems of Chamaecrista desvauxii and Clitoria laurifolia in a disturbed area, including flowering periods, floral attributes (morphology and resources), floral visitors and reproductive systems. Moreover, reproductive success rates based upon self-, cross-, and openpollination were compared through fruit/seed set and seed viability, considering the restricted availability of pollinators imposed by the habitat alteration.

\section{Materials and methods}

Study site - The study was carried out on a coastal plain of São Vicente municipality, São Paulo State, Brazil (2359'09.8'S 46²9'45.4'W). The study site is located in the Marine Terrace (Cananéia Formation), with slope below $2 \%$ and altitude lower than $5 \mathrm{~m}$ (Maciel 2001, Amorim \& Oliveira 2009). The soil type is Spodosol, sandy, strongly acidic, with ferrous deposits, low exchangeable bases, and Al-saturated CEC (Rodrigues 2006, Amorim \& Oliveira 2009).

The vegetation is classified as coastal plain high forest (CONAMA 1996) and the climate as type Aw, tropical humid with wet summers (Köppen 1948), with mean annual rainfall between 1,600 and 3,000 mm and mean temperature of $23{ }^{\circ} \mathrm{C}$. August is the driest month $(89.3 \mathrm{~mm})$ and most of rainfall occurs between January and March (ca. $280 \mathrm{~mm} / \mathrm{month}$ ).

The study area was subjected to deforestation and soil removal up to $2.5 \mathrm{~m}$ due to sand mining for at least two decades (Rodrigues 2006). In 1997, a restoration project was established which included the planting of seedlings and litter transposing. After that, seedling growth and development as well as natural succession were slower than expected (Fidalgo et al. 2009). Currently, a community of exotic and native herbs occur in this area, and Tibouchina clavata (Pers.) Wurdack (Melastomataceae), Clitoria laurifolia Poir. and Chamaecrista desvauxii (Collad.) Killip (Fabaceae) are the dominant species.

Phenology - Flowering phenology was studied from January 2006 to May 2008. At least twenty specimens of each species were selected prior to flowering. The number of flowers and fruits on each individual were counted once a month. Data was sorted by month, transformed into proportions, plotted in phenograms and analyzed by using circular statistics (Batschelet 1981), in order to determine which month of each year had the highest abundance of flowers and fruits per species.

Circular statistics are based on the analysis of points around a circle; the acrophase or mean angle is the phase in which there is the highest probability of finding the activity under observation. The reference point used was $0^{\circ}$ and the acrophase is represented by angular units (degrees). Mean vector length " $r$ " is a measure of concentration (minimum $=0$, maximum $=1$ ). Angular deviation " $s$ " serves as the dispersion measure (Batschelet 1981, Benedito-Silva 1997, Zar 1999). Rayleigh's test (Zar 1999) was used to obtain the significance of the acrophases. Bimodal data were ruled out of the analysis.

Floral biology and breeding system - Individuals of the two species studied were observed to determine the time of anthesis and flower longevity. In order to determine stigma receptivity, around 7:00 am, the stigmas of 10 fresh flowers, from 10 different individuals, were dissected and immersed in a drop of a $3 \%$ hydrogen peroxide $\left(\mathrm{H}_{2} \mathrm{O}_{2}\right)$ solution. The anthers 
of each flower were placed in a drop of aqueous acid fuchsine on a microscope slide (Dafni et al. 2005). They were then slightly squeezed to expose pollen grains; pollen with cellular content was stained red and considered viable.

Breeding systems were assessed by controlled pollination experiments. Pre-flowering buds were enclosed within polyester bags. At least 30 fresh flowers, from 20 to 30 different individuals, were submitted to the following treatments, emasculation (apomixis), spontaneous and manual self-pollination as well as manual cross-pollination. At least 30 inflorescences, from different individuals were tagged so that natural pollination could take place. The selfincompatibility index (ISI, sensu Bullock 1985) was calculated for each species.

The occurrence of pollen limitation was assessed by using the index of pollen limitation [IPL $=1-(\mathrm{Fn} /$ $\mathrm{Fcp})$ ]; where $\mathrm{Fn}$ is the percentage of fruiting in natural conditions and Fcp is the percentage of manual crosspollination. Negative values or near zero $(0.2)$ indicate absence of pollen limitation (PL) (Larson \& Barret 2000, Freitas et al. 2010). We also applied the $X^{2}$ test to assess differences between the fruit set of hand pollination treatments and natural pollination (Zar, 1999).

Pollinated flowers were monitored for 21 days until fruit maturation and the number of seeds per fruit was counted. Germination tests were carried out with 12 replications of 10 seeds on Germitest ${ }^{\circledR}$ previously imbibed in distilled water, at constant temperature $\left(25^{\circ} \mathrm{C}\right)$ and a 12-hour photoperiod for 30 days (Brasil 2009).

Visitors' composition and behavior - Based on the timing of anthesis, continuous direct observations on floral visitors were performed from sunrise to 01:00 - 02:00 pm, five days a week, during a month each year. The time spent on each species and the number of individuals sampled depended on the pollinators' behavior. Flower visitors were captured for identification, at the Zoology Museum (USP), and to examine pollen deposition on their body.

\section{Results}

Phenology - Chamaecrista desvauxii was the first species to flower (figure 1a). Throughout the first two years of observations, the most intense flowering period occurred around January $(r=0.9 ; \mathrm{p}<0.05$ and $r=0.8 ; \mathrm{p}<0.05$ for 2006 and 2007, respectively) and the most intense fruiting period between January and
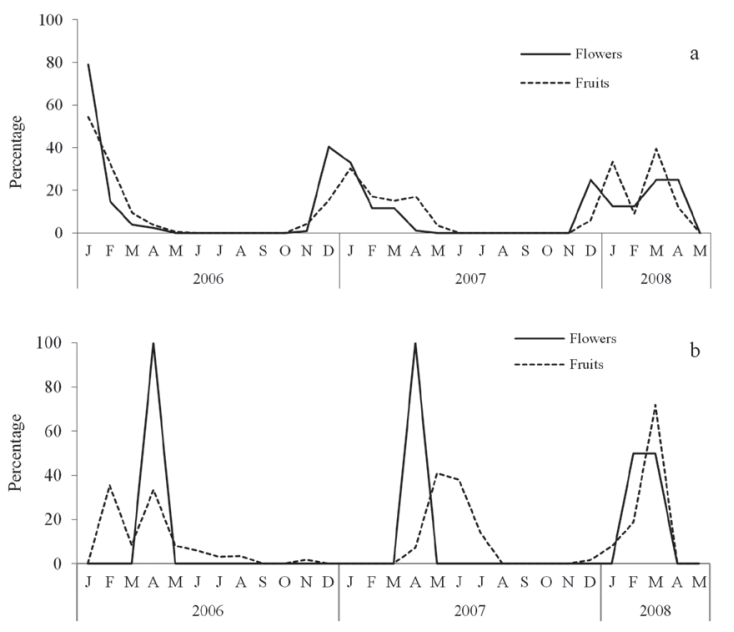

Figure 1. Flowering and fruiting intensity (\%) of (a) Chamaecrista desvauxii and (b) Clitoria laurifolia in São Vicente, SP.

February $(r=0.9 ; \mathrm{p}<0.05$ and $r=0.7 ; \mathrm{p}<0.05$ for 2006 and 2007, respectively). On the third year, the flowering periods occurred on December/2007 and March-April/2008. The fruiting periods occurred on January and March/2008 (figure 1a).

Clitoria laurifolia flowered on April 2006 and 2007 ( $r=1 ; \mathrm{p}<0.05$ and $r=1 ; \mathrm{p}<0.05$ ) (figure 1b). The fruiting periods occurred in February and April 2006 and between May and June 2007 ( $r=0.87$; $\mathrm{p}<0.05)$. In 2008 the reproductive events began earlier with intense flowering and fruiting occurring from February to March $(r=0,88 ; \mathrm{p}<0.05$ and $r=0,78 ; \mathrm{p}<0.05$, respectively).

Floral biology and breeding system - The two species studied presented flowers that open early in the morning (05:00-07:00 am) and last for only one day, fading and falling early in the afternoon (01:00-02:00 pm).

Chamaecrista desvauxii flowers offer only pollen as a reward. They are zygomorphyc, with five free yellow petals, ten yellow, heteromorphic stamens and a greenish pistil located above them. Their anthers open through apical slits and face towards the median larger petal. The flowers present enantiostyly, with two morphs being found on the same individual (monomorphic).

Clitoria laurifolia has zygomorphic butterfly shaped inverted flowers with papilionaceous features. Each flower has five lilac petals, one standard (pointing downwards), two wings and two keels, which enclose the monadelphous androecium with ten whitish stamens, free at the apices and fold at the base 
forming a tube. The pistil is longer than the stamens so the stigma stays above the anthers. Flowers produce pollen and nectar, which was actively collected.

Stigmas from both species were receptive during the whole anthesis. Pollen stainability was $74.6 \%$ $(\mathrm{SD}=13.8, \mathrm{n}=10)$ for $C$. desvauxii and $100 \%(\mathrm{n}=8)$ for C. laurifolia.

The controlled pollination experiments (table 1) indicated that both species are self-compatible. The values of the self-incompatibility index (ISI) were 1.04 and 1.36 to C. desvaxii and C. laurifolia, respectively.
Fruit set after hand pollinations in Chamaecrista desvauxii was similar $\left(X^{2}=0.09 ; \mathrm{p}>0.05\right)$ and seeds from these treatments presented germination rates $20 \%$ higher than in the control group (table 1). Furthermore, natural fruit set (control) was significantly lower when compared to manual self- and cross-pollinations $\left(X^{2}=7.52 ; \mathrm{p}<0.01\right.$ and $X^{2}=6.89 ; \mathrm{p}<0.01$, respectively). The index of pollen limitation for the species was 0.38 .

Regarding C. laurifolia, the fruit set in the control group was higher than after hand self-

Table 1. Results for pollination and germination experiments with Chamaecrista desvauxii $(\mathrm{Cd})$ and Clitoria laurifolia $(\mathrm{Cl})$.

\begin{tabular}{lcccccc}
\hline \multirow{2}{*}{ Treatments } & \multicolumn{2}{c}{$\%$ de success $\left(\mathrm{Fl} / \mathrm{Fr}^{*}\right)$} & \multicolumn{2}{c}{ Number of seeds/fruit } & \multicolumn{2}{c}{ \% of germination } \\
\cline { 2 - 7 } & $\mathrm{Cd}$ & $\mathrm{Cl}$ & $\mathrm{Cd}$ & $\mathrm{Cl}$ & $\mathrm{Cd}$ & $\mathrm{Cl}$ \\
\hline Self-pollination & $78.1(32 / 25)$ & $59.5(37 / 22)$ & $12.4 \pm 4.9$ & $5.2 \pm 1.6$ & 91.6 & 42.4 \\
Cross-pollination & $75.0(40 / 30)$ & $43.8(48 / 21)$ & $9.5 \pm 3.6$ & $6.3 \pm 1.9$ & 93.9 & 49.5 \\
Spontaneous self-pollination & $0(48 / 0)$ & $10.9(46 / 5)$ & - & $4.2 \pm 1.4$ & - & 31.2 \\
Apomixis & $0(33 / 0)$ & $2.8(36 / 1)$ & - & - & - & - \\
Control & $46.1(39 / 18)$ & $78.0(50 / 39)$ & $10.6 \pm 4.8$ & $6.8 \pm 2.9$ & 71.1 & 99.2 \\
\hline
\end{tabular}

$*(\mathrm{Fl} / \mathrm{Fr})=($ Flowers $/$ Fruits $)$

and cross-pollination $\left(X^{2}=3.48 ; \mathrm{p}<0.05\right.$ and $X^{2}=12.10 ; \mathrm{p}<0.001$, respectively) as well as the seed germination, hand pollinations were not statistically different $\left(X^{2}=2.06, \mathrm{p}>0.05\right)$ (table 1). Fruits and seeds were set through spontaneous self-pollination. The index of pollen limitation was -0.78 .

Visitors' behavior - The two species were pollinated by bees. Bombus (Fervidobombus) morio (Swederus, 1787) and Eufriesea sp. visited the flowers of both species whereas Eulaema (Apeulaema) cingulata (Fabricius, 1804) visited only C. desvauxii (table 2). The relative frequency of visits to $C$. desvauxii was $75 \%$ for B. morio, $23 \%$ for Eufrisea sp. and $2 \%$ for $E$. cingulata. C. laurifolia was visited by B. morio $(81 \%$ of visits) and also by Eufrisea sp (7\%).

The three bee species visiting $C$. devauxii collected pollen by vibration performing at least two approaches per flower in 10 seconds. Nearly four to five flowers were visited in sequence. Bombus morio was slower spending more time on each flower, compared to other species, and performing up to four vibrations from different positions. All visitors touched the stigma with the ventral portions of the thorax and abdomen, the same areas of pollen deposition.

Bees visiting C. laurifolia (table 2) landed on the flower central area and inserted the tongue laterally between the wings and the keel, forcing this complex downwards. The reproductive column emerged from the keel, the stigma touched the ventral portion of the bee abdomen first, and then a little cloud of pollen was released and reached the same area of the bee body. After the insect's visit, the flower parts returned to the initial position, so that flowers could be visited several times. This triggering mechanism was referred as 'brush mechanism' by Arone et al. (2012).

Besides bees, one Lepidoptera species visited $C$. laurifolia accessing the nectary without triggering the mechanism that exposes the reproductive structures and it was considered as a nectar thief (sensu Inouye 1980) (table 2).

The presence of the first visitors was recorded from 5:00 am to $C$. desvauxii and 6:30 am to C. laurifolia with peak at 06:30 am and between 8:30 and 10:00 am, respectively. The more frequent species visiting $C$. desvauxii and C. laurifolia was Bombus morio. These visited $C$. desvauxii in search for pollen from 5:00 am. Nectar became the main resource, collected in C. laurifolia, between 8:00 and 10:00 am (figure 2). Eufrisea sp. did not shown a clear pattern in nectar and pollen foraging, collecting both early in the morning. Eulaema cingulata only collected pollen on C. desvauxii. 
Table 2. Insect species visiting $C$. desvauxii $(\mathrm{Cd})$ and $C$. laurifolia $(\mathrm{Cl})$ on the study area.

\begin{tabular}{lccc}
\hline Subfamily/ Tribe/ Specie* & Plant visited & Behavior & Pollinator \\
\hline Hymenoptera & & & \\
$\quad$ Apinae/Apini & & & \\
$\quad$ Bombus morio (Sewederus 1787) & $\mathrm{Cd} / \mathrm{Cl}$ & buzz & yes \\
$\quad$ Eufriesea sp. & $\mathrm{Cd} / \mathrm{Cl}$ & buzz & yes \\
$\quad$ Eulaema (Apeulaema) cingulata (Fabricius 1804) & $\mathrm{Cd}$ & buzz & yes \\
Lepidoptera & $\mathrm{Cl}$ & nectar thief & no \\
\hline
\end{tabular}

* Bee classification follows Michener (2000)

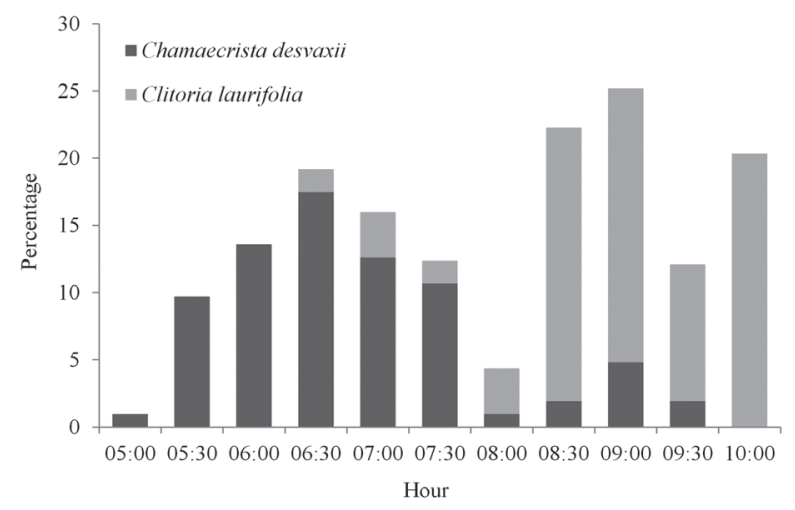

Figure 2. Relative frequency of Bombus morio visits to Chamaecrista desvauxii and Clitoria laurifolia.

\section{Discussion}

In this study, $C$. desvauxii presented intense flowering in the rainy season and consequently their fruits and seeds matured at the transition to dry season. On the other hand, C. laurifolia flowered at the end of the wet season with fruits and seeds maturing mainly in the dry season. According to Walter (1983), the region of São Vicente can be considered weakly seasonal since rainfall is above $60 \mathrm{~mm}$ in the driest periods of the year. However, studies with other botanical families in Restinga found the relationship among the phenophases and the volume of rainfall with budding and flowering occurring mainly in the wet periods (Talora \& Morellato 2000, Marques \& Oliveira 2004, Fidalgo \& Kleinert 2009). The species exhibited intraspecific synchrony but interspecific asynchrony in flowering, these characteristics increase their attractiveness to pollinators and the chances of cross-pollination, while reducing competition for the pollinators they share in the study area and the heterospecific pollen transfer (Augspurger 1983, Elzinga 2007, Ashman \& Arceo-Gomez 2013).

The two species have flowers presenting several features associated to melittophily (Endress 1994,
Proctor et al. 1996). For example, they are yellow, blue or purple, zygomorphic, with three-dimensional shape and supply pollen as the main or the only reward. Additionally, their morphology restricts the number of effective pollinators through mechanisms which limit bee access to floral rewards, such as anthers functionally poricidal in $C$. desvauxii and the triggering mechanism in C. laurifolia. This can reduce the number of visitors as well as pollinators but, on the other hand, bees tend to visit a greater number of flowers of the same species, making cross-pollination more efficient and less costly (Goulson 1994, Laverty 1994).

Only three different bees have been observed as flowers visitors for both studied species, which is a very low number compared to other studies. Oliveira \& Sigrist (2008) recorded 18 visitors to a Faboideae species, which featured the same pollination mechanism as C. laurifolia, including bees, wasps, flies, butterflies, and hummingbirds. Other authors mentioned the presence of 11 to 20 species in up to five orders of insects for Fabaceae species (Manente-Balestieri \& Machado 1999, Stout et al. 2002, Carvalho \& Oliveira 2003, Nascimento \& DelClaro 2007), as well as birds and rodents (Tandon et al. 2003, Borges et al. 2009). Several species of the genus Chamaecrista are pollinated by large bees, which perform vibration to collect pollen, especially from the genera Bombus, Centris and Xylocopa (Aguiar 2003, Liu \& Koptur 2003, Albuquerque et al. 2007, Nascimento \& Del-Claro 2007, Oliveira-Rebouças \& Gimenes 2011, Almeida et al. 2013 and 2015, Figueiredo et al. 2013).

Even considering the constraints imposed by floral morphology, the low richness and abundance of floral visitors observed seem to be related to the environmental degradation of the study area. Some of the main restrictions imposed by it to the establishment 
and survival of bees were intense heat, strong winds and low availability of flowering species and sites suitable for nesting. Nevertheless, these bees were legitimate pollinators as they were able to access the pollen releasing mechanism from both species. They have a similar visiting pattern, coming in and out of the plants at the same direction, which suggests the maintenance of foraging routes ("trap-lining") among individuals. Bees that carry out "trap-lining" are efficient in transferring pollen between distant individuals of small populations, and they may promote cross-pollination (Endress 1994, Carvalho \& Oliveira 2003). However, B. morio was the only very effective pollinator in the area, since it was present throughout the whole visitation period, showing the highest frequency among all visitors (sensu Freitas 2013).

Our results showed that, when both species were flowering, B. morio switches from collecting C. desvauxii pollen to $C$. laurifolia nectar during the foraging period (figure 2). According to Konsmann \& Lunau (2014) only very few bumblebees specialize in collecting only one resource since most workers gather nectar and/or pollen. Bombus impatiens foragers can specialize in pollen or nectar foraging to some level depending on the first foraging trips, however they may switch if storage levels change (Hagbery \& Nieh 2012). Furthermore, according to Souza et al. (2017), B. morio showed a daily temporal partitioning in floral visits to synchronopatric species of Vigna, which possibly reduced interspecific pollen flow. Heterospecific pollen transfer can reduce reproductive success if it is frequent and/or intense (Ashman \& Arceo-Gomez 2013). At the studied area, Bombus morio behavior may allow the bees to maximize their efficiency as foragers by collecting pollen earlier, that is, before it is no longer available, as well as pollinators by reducing heterospecific pollen transfer.

Chamaecrista desvauxii and Clitoria laurifolia were both self-compatible but the presence of visitors was obligatory for self-pollination only for the first species. Despite being predominantly allogamous, several Fabaceae species are partially self-compatible forming fruits after self-pollinations, although they require a vector to perform pollination (ManenteBalestieri \& Machado 1999, Tandon et al. 2003, Nair et al. 2004, Kleunen \& Johnson 2005, Galloni et al. 2007, Arone et al. 2012). Self-compatibility is not considered prevalent in the genus Chamaecrista, but it has already been reported for species in Mexico and
Brazil (Biondo et al. 2006, Arceo-Gómez et al. 2012, Almeida et al. 2013 and 2015).

Chamaecrista desvaxii presented enantyostyly, a common feature to the genus and to the subtribe Cassiinae (Marazzi et al. 2006, Almeida et al. 2013 and 2015), to which authors have suggested may reduce geytonogamy and favor cross-pollination (Jesson \& Barrett 2003, Jesson et al. 2003). However, bee movements within the flowers results in pollen deposition all over their abdomen, in both morphs, allowing intra floral self-pollination and geytonogamy.

Self-compatibility is an important strategy for pioneering species to occupy new areas (Ribeiro \& Lovato 2004), mainly in plants in the early stages of ecological succession (Opler et al. 1980). The main advantage of self-compatibility is the increased likelihood of pollination success (Bawa 1974) and the lower reproductive susceptibility to habitat fragmentation (Aguilar et al. 2006). Small populations subjected to harsh environments may suffer selection pressure for self-compatibility as a response to the uncertainty pollination during flowering periods, the occurrence of pollination failures or the absence of pollinators (Endress 1994, Kaye 1999, Arceo-Gómez et al. 2012).

Clitoria laurifolia showed great adaptability to bear fruit even through spontaneous selfing, which favors the species establishment in pollenconstrained environments. Other Fabaceae species, such as Lupinus perennis L. and Astragalus australis var olympicus Isely, exhibit behavior similar to Clitoria laurifolia, and they may suffer spontaneous selfing in case of drastic reduction in population size or pollinator limitation as a way to ensure the reproductive success, despite being reduced (Kaye 1999, Shi et al. 2005).

The low number of seeds produced based on pollen limitation is the result of insufficient quantity of pollen deposition associated with scarce and/ or inefficient floral visitors or even limited quality of pollen related to selfing or heterospecific pollen transportation (Pérez-Bañón et al. 2003, Ashman et al. 2004, Jacobi \& Sarto 2007, Aizen \& Harder 2007, Alonso et al. 2013). Habitat alteration and fragmentation can increase pollen limitation through the reduction in pollination efficiency by affecting pollinator size, abundance and behavior, besides creating an unpredictable pollination environment (Lazaro \& Travese 2006, Aguilar et al. 2006, Alonso 
et al. 2013, Suarez-Gonzales \& Good 2014, Warzecha et al. 2016).

Although the recruitment and survival of Chamaecrista desvauxii's population in the study area were high, the number of pollinator species observed were quite reduced. The most obvious consequence of this restriction was the lower fruit set under natural conditions (table 1) possibly by pollen limitation (IPL 0.38). For instance Chamaecrista keynensis, a selfcompatible species that also depends upon pollinators for fruit set, suffered pollen limitation associated with low availability of buzz pollinating bees in urban edge areas (Liu \& Koptur 2003). According to Ashman et al. (2004), some of the most extremes effects in PL of seed production are reported for plants in disturbed systems.

The two species studied have similar reproductive strategies and supply different food sources to the same small group of bees, which rely on them to feed in the study area. Such food sources allow the pollinators to survive and ensure plant reproductive success despite environmental restrictions. Conversely, $C$. desvauxii showed higher dependence on available pollinators, which makes this species more susceptible to environmental disturbances and pollen limitation.

\section{Acknowlegments}

The authors wish to thank the anonymous reviewers for proof-reading the manuscript and Dr. Rodrigo B. Gonçalves and Dr. Kelli S. Ramos for bee identification. Mr. O. Vieira is acknowledged for the language review. We are also thankful to $\mathrm{CNPq} / \mathrm{PIBIC}$ for the grant to Gabriela Toledo Caldiron. This study was part of the master degree Dissertation by Débora Marcouizos Guimarães to the Plant Biodiversity and Environment Postgraduate Program of the Instituto de Botânica de São Paulo.

\section{Literature cited}

Aguiar, C.M.L. 2003. Flower visits of Centris bees (Hymenoptera: Apidae) in an area of caatinga (Bahia, Brazil). Studies on Neotropical Fauna and Environment 38: 41-45.

Aguilar, R., Ashworth, L., Galetto, L. \& Aizen, M. 2006. Plant reproductive susceptibility to habitat fragmentation: review and synthesis through a metaanalysis. Ecology Letters 9: 968-980.

Aizen, M.A. \& Harder, L.D. 2007. Expanding the limits of the pollen-limitation concept: effects of pollen quantity and quality. Ecology 88: 271-281.
Albuquerque, P.M.C., Camargo, J.M.F. \& Mendonça, J.A. 2007. Bee community of a Beach Dune ecossystem on Maranhão Island, Brazil. Brazilian Archives of Biology and Technology 6: 1005-1018.

Almeida, N.M., Castro C.C., Lima Leite A.V., Novo, R.R. \& Machado, I.C. 2013. Enantiostyly in Chamaecrista ramosa (Fabaceae-Caesalpinioideae): floral morphology, pollen transfer dynamics and breeding system. Plant Biology 15: 369-375.

Almeida, N.M., Bezerra, T.T., Oliveira, C.R.S., Novo, R.R., Siqueira-Filho, J.A., Oliveira, P.E. \& Castro, C.C. 2015. Breeding systems of enantiostylous Cassiinae species (Fabaceae, Caesalpinioideae). Flora 215: 9-15.

Alonso, C., Navarro-Fernández, M.D., Arceo-Gómez, G., Meindl, G.A., Parra-Tabla, V. \& Ashman, T.L. 2013. Among-species differences in pollen quality and quantity limitation: implications for endemics in biodiverse hotspots. Annals of Botany-London 112: 1461-1469.

Amorim, R.R. \& Oliveira, R.C. 2009. O estudo das unidades de relevo em municípios da faixa costeira brasileira: o exemplo do município de são Vicente - SP. Caminhos de Geografia 10: 163-183.

Arceo-Gómez, G., Martinez, M.L., Parra-Tabla, V. \& Garcia-Franco, J.G. 2012. Floral and reproductive biology of the Mexican endemic Chamaecrista chamaecristoides (Fabaceae). Journal of Torrey Botanical Society 139: 260-269.

Arone, G., Giovanetti, M. \& De Micco, V. 2012. Traits and pollination mechanisms of Coronilla emerus L. flowers (Fabaceae). Scientific World Journal 2012: 1-8.

Ashman, T.L., Knight, T.M., Steets, J.A., Amarasekare, P., Burd, M., Campbell, D.R., Dudash, M.R., Johnston, M.O., Mazer, S.J., Mitchell, R.J., Morgan, M.T. \& Wilson, G.W. 2004. Pollen limitation of plant reproduction: ecological and evolutionary causes and consequences. Ecology 85: 2408-2421.

Ashman, T.L. \& Arceo-Gómez, G. 2013. Toward a predictive understanding of the fitness costs of heterospecific pollen receipt and its importance in coflowering communities. American Journal of Botany 100: 1061-1070.

Augspurger, C.K. 1983. Phenology, flowering synchrony and fruit set of six neotropical shrubs. Biotropica 15: 257-267.

Batschelet, E. 1981. Circular statistics in biology. Academic Press, London.

Bawa, K.S. 1974. Breeding systems of tree species of a lowland tropical community. Evolution 28: 85-92.

Benedito-Silva, A.A. 1997. Aspectos metodológicos da cronobiologia. In: N. Marques, L. Menna-Barreto (orgs.). Cronobiologia: Princípios e Aplicações, Editora da Universidade de São Paulo, São Paulo, pp. 215-238. 
Biondo, E., Miotto, S.T.S. \& Schifino-Wittmann, M.T. 2006. Cytogenetics of species of Chamaecrista (Leguminosae-Caesalpinioideae) native to southern Brazil. Botanical Journal of the Linnean Society 150: 429-439.

Borges, L.A., Sobrinho, M.S. \& Lopes, A.V. 2009. Phenology, pollination and breeding system of the threatened tree Caesalpinia echinata Lam (Fabaceae) and a review of studies on the reproductive biology in the genus. Flora 204: 111-130.

Brasil. Ministério da Agricultura e Reforma Agrária. 2009. Regras para análise de sementes. SNDA/DNDV/CLAV, Brasília.

Brito, V.L.G., Pinheiro, M. \& Sazima, M. 2010. Sophora tomentosa and Crotalaria vitellina (Fabaceae): reproductive biology and interactions with bees in the restinga of Ubatuba, São Paulo. Biota Neotropica 10: 185-192

Bullock, S.H. 1985. Breeding systems in the flora of a tropical deciduous forest in Mexico. Biotropica 17: 287-301.

Carvalho, D.A. \& Oliveira, P.E. 2003. Biologia reprodutiva e polinização de Senna sylvestris (Vell.) H.S. Irwin and Barneby (Leguminosae, Caesalpinioideae). Brazilian Journal of Botany 26: 319-328.

Conselho Nacional do Meio Ambiente. 1996. Resolução CONAMA 007/96, de 23 de julho de 1996. Aprova os parâmetros básicos para análise da vegetação de restingas no Estado de São Paulo. Diário Oficial da União, 26-VIII-1996, Seção I, n.165, pp. 16386-16390.

Dafni, A., Kevan, P.G. \& Husband, B.C. 2005. Practical pollination biology. Environquest, Cambridge.

Endress, P.K. 1994. Diversity and evolutionary biology of tropical flowers. Cambridge University Press, Cambridge.

Elzinga, J.A. , Atlan, A., Arjen, B., Gigord, L., Weis, A.E. \& Bernasconi, G. 2007. Time after time: flowering phenology and biotic interactions. Trends in Ecology and Evolution 22: 432-439.

Fidalgo, A.O. \& Kleinert, A.M.P. 2009. Reproductive biology of six Brazilian Myrtaceae: is there a syndrome associated with buzz-pollination? New Zealand Journal of Botany 47: 355-365.

Fidalgo, A.O., Alcântara, R.P. \& Oliveira, G.T. 2009. Parâmetros de crescimento na avaliação de uma floresta implantada em uma restinga degradada pela mineração. Revista Brasileira de Biociências 7: 382-386.

Figueiredo, N., Gimenes, M., Miranda, M.D. \& OliveiraRebouças, P. 2013. Xylocopa bees in tropical coastal sand dunes: use of resources and their floral syndromes. Neotropical Entomology 42: 252-257.

Freitas, L. 2013. Concepts of pollinator performance: is a simple approach necessary to achieve a standardized terminology? Brazilian Journal of Botany 36: 3-8.
Freitas, L., Wolowski, M. \& Sigiliano, M.I. 2010. Ocorrência de limitação polínica em plantas de Mata Atlântica. Oecologia Australis 14: 251-265.

Galloni, M., Podda, L., Vivarelli, D. \& Cristofolini, G. 2007. Pollen presentation, pollen-ovule ratios, and other reproductive traits in Mediterranean Legumes (Fam. Fabaceae - Subfam. Faboideae). Plant Systematics and Evolution 266: 147-164.

Ghazoul, J. 2006. Floral diversity and the facilitation of pollination. Journal of Ecology 94: 295-304.

Goulson, D. 1994. A model to predict the role of flower constancy in inter-specific competition between insect pollinated flowers. Journal of Theoretical Biology 168: 309-314.

Hagbery, J. \& Nieh, J.C. 2012. Individual lifetime pollen and nectar foraging preferences in bumble bees. Naturwissenschaften 99: 821-832.

Inouye, D.W. 1980. The terminology of floral larceny. Ecology 61: 1251-1253.

Jacobi, C.M. \& Sarto, M.C. 2007. Pollination of two species of Vellozia (Velloziaceae) from high-altitude quartzitic grasslands, Brazil. Acta Botanica Brasilica 21: 325-333

Jesson, L.K. \& Barrett, S.C.H. 2003. The comparative biology of mirror-image flowers. International Journal of Plant Science 164: 237-245.

Jesson, L.K., Barrett, S.C.H. \& Day, T. 2003. A theoretical investigation of the evolution and maintenance of mirrorimage flowers. American Naturalist 161: 916-930.

Kaye, T.N. 1999. From flowering to dispersal: reproductive ecology of an endemic plant, Astragalus australis var olympicus (Fabaceae). American Journal of Botany 86: $1248-1256$.

Kearns, C.A., Inouye, D.W. \& Waser, N.M. 1998. Endangered mutualisms: the conservation of plantpollinator interactions. Annual Review of Ecology and Systematics 29: 83-112.

Kissman, K.G. \& Groth, D. 1995. Plantas infestantes e nocivas. v.2, BASF, São Bernardo do Campo.

Kleunen, M.V. \& Johnson, S.D. 2005. Testing for ecological and genetic Allee effects in the invasive shrub Senna didymobotrya (Fabaceae). American Journal of Botany 92: 1124-1130.

Konsmann, S. \& Lunau, K. 2014. Divergent rules for pollen and nectar foraging bumblebees - a laboratory study with artificial flowers offering diluted nectar substitute and pollen surrogate. PLoS ONE 9: e91900.

Köppen, W. 1948. Climatologia. Fondo de Cultura Econômica, México.

Larson, B.M.H. \& Barrett, S.C.H. 2000. A comparative analysis of pollen limitation in flowering plants. Biological Journal of the Linnean Society 69: 503-520.

Laverty, T.M. 1994. Costs to foraging bumblebees of switching plant species. Canadian Journal of Zoology 72: 43-47. 
Lazaro,A. \& Traveset, A. 2006. Reproductive success of the endangered shrub Buxus balearica (Buxaceae): Pollen limitation, and inbreeding and outbreeding depression. Plant Systematics and Evolution 261: 117-128.

Liu, H. \& Koptur, S. 2003. Breeding system and pollination of a narrowly endemic herb of the lower Florida Keys: impacts of the urban-wildland interface. American Journal of Botany 90: 1180-1187.

Maciel, G.C. 2001. Zoneamento Geoambiental do Município de São Vicente (SP), utilizando o Sistema de Informação Geográfica - SIG. Dissertação de Mestrado, Universidade de São Paulo, São Carlos.

Manente-Balestieri, F.C.D.L. \& Machado, V.L.L. 1999. Entomofauna visitante das flores de Cassia spectabilis (L.) D C. (Leguminosae). Anais da Sociedade Entomológica do Brasil 28: 429-437.

Marazzi, B., Endress, P.K., Queiroz, P.L. \& Conti, E. 2006. Phylogenetic relationships within Senna (Leguminosae, Cassiinae) based on three chloroplast DNA regions: patterns in the evolution of floral symmetry and extrafloral nectaries. American Journal of Botany 93: 288-303.

Marques, M.C.M. \& Oliveira, P.E.A.M. 2004. Fenologia de espécies do dossel e do sub-bosque de duas florestas de restinga na Ilha do Mel, sul do Brasil. Brazilian Journal of Botany 27: 713-723.

Martínez, M.L. 2003. Facilitation of seedling establishment by an endemic shrub in tropical coastal sand dunes. Plant Ecology 168: 333-345.

Martínez, M.L., Gallego-Fernández, J.B., GarcíaFranco, J.G., Moctezuma, C. \& Jiménez, C.D. 2006. Assessment of coastal dune vulnerability to natural and anthropogenic disturbances along the Gulf of Mexico. Environmental Conservation 33: 109-117.

Michener, C.D. 2000. The bees of the world. Johns Hopkin, Baltimore.

Nair, R.M., Dundas, I.S., Wallwork, M., Verlin, D.C., Waterhouse, L. \& Dowling, K. 2004. Breeding system in a population of Trigonella balansae (Leguminosae). Annals of Botany-London 94: 883-888.

Nascimento, E.A. \& Del-Claro, K. 2007. Floral visitors of Chamaecrista debilis (Vogel) Irwin and Barneby (Fabaceae - Caesalpinoideae) at cerrado of Estação Ecológica de Jataí, São Paulo State, Brazil. Neotropical Entomology 36: 619-624.

Oliveira, M.I.B. \& Sigrist M.R. 2008. Fenologia reprodutiva, polinização e reprodução de Dipterix alata Vogel (Leguminosae-Papilionoidae) em Mato Grosso do Sul, Brasil. Brazilian Journal of Botany 31: 195-207.

Oliveira-Rebouças, P. \& Gimenes, M. 2011. Potential pollinators of Comolia ovalifolia DC Triana (Melastomataceae) and Chamaecrista ramosa (Vog.) H.S. Irwin and Barneby var. ramosa (LeguminosaeCaesalpinioideae), in restinga, Bahia, Brazil. Revista Brasileira de Biologia 71: 343-351.
Opler, P.A., Baker, H.G. \& Frankie, G.W. 1980. Plant reproductive characteristics during secondary succession in Neotropical Lowland Forest ecosystems. Biotropica 12: 40-46.

Pérez-Bañón, C., Juan, A., Petanidou, T., MarcosGarcia, M.A. \& Crespo, M.B. 2003. The reproductive ecology of Medicago citrina (Font Quer) Greuter (Leguminosae): a bee-pollinated plant in mediterranean islands where bees are absent. Plant Systematics and Evolution 241: 29-46.

Primm, S.L. \& Raven, P. 2000. Extinction by numbers. Nature 403: 843-845.

Proctor, M., Yeo, P. \& Lack, A. 1996. The natural history of pollination. Harper Collins Publishers Co, London.

Ribeiro, R.A. \& Lovato, M.B. 2004. Mating system in a neotropical tree species, Senna multijuga (Fabaceae). Genetics and Molecular Biology 27: 418-424.

Rodrigues, M.A. 2006. Avaliação da chuva e banco de sementes em áreas de restinga, morfoecologia e potencial biótico de espécies ocorrentes nestes locais. Dissertação de Mestrado, Universidade Estadual Paulista, Rio Claro.

Rocha, C.F.D., Bergallo, H.G., van Sluys, M., Alves, M.A.S. \& Jamel, C.E. 2007. The remnants of restinga habitats in the Brazilian Atlantic Florest of Rio de Janeiro state, Brazil: Habitat loss and risk of disappearance. Brazilian Journal of Biology 67: 263-273.

Rosales, J., Guenca, G., Ramírez, N. \& Andrade, Z. 1997. Native colonizing species and degraded land restoration in La Gran Sabana, Venezuela. Restoration Ecology 5: 147-155.

Sacramento, A.C., Zickel, C.S. \& Almeira Jr, E.B. 2007. Aspectos florísticos da vegetação de restinga no litoral de Pernambuco. Árvore 31: 1121-1130.

Scarano, F.R. 2002. Structure, function and floristic relationships of plant communities in stressful habitats marginal to the Brazilian Atlantic rainforest. Annals of Botany-London 90: 517-524.

Shi, X.J., Michaels, H.J. \& Michel, R.J. 2005. Effects of self-pollination and maternal resources on reproduction and offspring performance in thewild lupine, Lupinus perennis (Fabaceae). Sexual Plant Reproduction 18: 55-64.

Silva, W.L.S., Rocha, A.E. \& Santos, J.U.M. 2014. Leguminosae em savanas do estuário amazônico brasileiro. Rodriguésia 65: 329-353.

Souza, J.M.T., Snak, C. \& Varassin, I.G. 2017. Floral divergence and temporal pollinator partitioning in two synchronopatric species of Vigna (LeguminosaePapilionoideae). Arthropod-Plant Interactions 11: 285-297.

Stout, J.C., Kells, A.R. \& Goulson, D. 2002. Pollination of the invasive exotic shrub Lupinus arboreus (Fabaceae) by introduces bees in Tasmania. Biological Conservation 106: 425-434. 
Suarez-Gonzalez, A. \& Good, S.V. 2014. Pollen limitation and reduced reproductive success are associated with local genetic effects in Prunus virginiana, a widely distributed self-incompatible shrub. Annals of BotanyLondon 113: 595-605.

Talora, D.C. \& Morellato, L.P.C. 2000. Fenologia de floresta de planície litorânea. Brazilian Journal of Botany 23: 13-26.

Tandon, R., Shivanna, K.R. \& Mohan Ram, H.Y. 2003. Reproductive biology of Butea monosperma (Fabaceae). Annals of Botany-London 92: 715-723.
Walter, H. 1983. Vegetation on earth. Spring-Verlag, New York. Warzecha, D., Diekötter, T. Wolters, V. \& Jauker, F. 2016. Intraspecific body size increases with habitat fragmentation in wild bee pollinators. Landscape Ecology 31: 1449-1455.

Zamith, L.R. \& Scarano, F.R. 2006. Restoration of a restinga sandy coastal plain in Brazil: survival and growth of planted woody species. Restoration Ecology 14: 87-94.

Zar, J.H. 1999. Bioestatistical analysis. Prentice Hall, Upper Saddle River. 